\title{
INHIBITORY ACTIVITY OF ENDOPHYTIC FUNGI ISOLATED FROM SUKABUMI TURMERIC PLANT (Curcuma longa L.) TOWARDS MCF-7 CELL LINE
}

\author{
Ratih Asmana Ningrum*, Bustanussalam, Popi Hadi Wisnuwardhani, Neng \\ Herawati, Adi Santoso, Partomuan Simanjuntak.
}

Research Center for Biotechnology Indonesian Institute of Sciences. Jalan Raya Bogor km 46 Cibinong 16911

Submitted: $11-08-2016$

Revised: 25-09-2016

Accepted: $10-11-2016$

${ }^{*}$ Corresponding author Ratih Asmana Ningrum

Email:

ratih.asmana@gmail.com

\begin{abstract}
Kunyit or turmeric plant (Curcuma longa L.) is a native southern Asia plant that has been widely used as herbal medicine. In our previous research, we isolated and screened 44 of endophytic fungi of turmeric plant from Sukabumi and Cibinong to determine their antioxidant activity. There were 4 samples isolated from Sukabumi with antioxidant activity for more than $70 \%$ at concentration of 100 ppm, K.Cl.Sb.R9 (93\%), K.Cl.Sb.A11 (81\%), K.Cl.Sb.B1 (79\%) and K.Cl.Sb.R11 (71\%). This research aimed to determine inhibitory activity of the endophytic fungi towards estrogen positive MCF-7 breast cancer cell line. To obtain the filtrate, the broth cultures were filtered and the extracellular fraction was extracted with ethylacetate. The inhibitory activity was determined by using MTT assay. The result showed that the ability of endophytic fungi to inhibit MCF-7 growth was dose-dependent. IC $_{50}$ of endophytic fungi K.Cl.Sb.R9 was $579 \pm 38$ ppm, K.Cl.Sb.R11 was $542 \pm 21 \mathrm{ppm}$, K.Cl.Sb.B1 was $446 \pm 15 \mathrm{ppm}$ and K.Cl.Sb.A11 was $520 \pm 28 \mathrm{ppm}$. Fluorescent double staining based method using calcein AM and ethidium bromide was performed to confirm the inhibitory activity. At $500 \mathrm{ppm}$ of filtrate concentration with $24 \mathrm{~h}$ of cell treatment, treated cell lines showed fewer viable cells compared to untreated cell lines. To conclude, the four isolates of endophytic fungi are able to inhibit proliferation of human breast cancer MCF-7 cell line.
\end{abstract}

Key words: MCF-7, inhibitory activity, endophytic fungi, turmeric plant.

\section{INTRODUCTION}

Turmeric plant is one of the herbal plants which belong to the group of gingers (Zingiberaceae) and originated from the Southeast Asia. Currently, the plant is widely cultivated in the tropical and subtropical area of the world. Turmeric has a rhizome containing curcuminoid, essential oils, carbohydrates and minerals (Krup et al., 2013). There are many studies on turmeric extracts from cell culture to animal trial which reported its potential as therapeutic agents in diseases, such as inflammatory bowel, arthritis, colon cancer, pancreatic cancer and cervical neoplasia. The extract showed various activities as well, including antioxidant, antimicrobial, antiangiogenesis, antitriglyceride, hepatoprotective and cardioprotective (Li et al., 2011; Ikpeama et al., 2014).

Curcuma longa $L$. has associated with endophytic microbes. The endophytic microbe is microorganisms that colonized with plant tissue without causing any adverse effect. It produces biological compounds as well as secondary metabolites in accordance with the host plant. The ability to produce bioactive compounds together with the host is a potential source of medicinal raw materials utilization (Zakiyah et al., 2015; Dompeipen, 2015). As the most phytochemically investigated species of Curcuma, Curcuma longa resulted in 235 compounds with various activities that have been identified and isolated from the flowers, leaves, roots and rhizomes which primarily are phenolic and terpenoid compounds. Thus, exploring endophytic microbes from Curcuma longa $L$ increases the possibility to discover novel compound which is substantial in resistance issues (Alvin et al, 2014).

One of the endophytic microorganisms of Curcuma longa L. is fungi. Fusarium nivale, F. 
Solani, Doratomyces stemonitis, Penicillium sp, Diaphorte sp were species that found in Curcuma longa (Ashraf and Javaid, 2005; Singh et al, 2014; Maehara et al, 2011). Various studies have reported the potential of endophytic fungi from the plant as antioxidant, antidiabetic antimicrobial and antitumor. Currently, more than 100 compounds have been isolated from fungi with high potential of antitumor activities (Suryanarayanan et al., 2009).

Our previous studies have isolated 44 endophytic fungi isolates of turmeric from Sukabumi and Cibinong. The results of antioxidant activity determination showed that there were 4 isolates from Sukabumi with high antioxidant activity for more than $70 \%$, namely K.Cl.Sb.R9 (93\%), K.Cl.Sb.A11 (81\%), K.Cl.Sb. B1 $(79 \%)$ and K.Cl.Sb.R11 (71\%)(Bustanussalam et al., 2015; Widowati et al., 2016). This study aims to determine the inhibitory activity of endophytic fungi towards human cancer cell line using human breast cancer cell line MCF-7 as a model.

\section{MATERIALS AND METHODS Isolate cultivation, fermentation, and extraction \\ Each isolate from previous research} (Bustanussalam et al., 2015) was cultivated in Potato Dextrose Agar and incubated at room temperature for 48-72h. The isolates were fermented in 2L of Potato Dextrose Broth at $150 \mathrm{rpm}$ for 3 days. The broth cultures were vacuum filtered to obtain the filtrates. The filtered filtrates were extracted using ethylacetate and dried by rotavapor. The dried filtrate was redissolved in Dimethyl Sulfoxide (Merck, Germany). Various concentrations of filtrate $(100 \mathrm{ppm}$ to $800 \mathrm{ppm})$ were used to treat the MCF-7 cell line.

\section{MCF-7 cell line propagation and treatments}

MCF-7 cells (from mammalian cell culture laboratory, Indonesian Institutes of Sciences) were thawed and washed with $9 \mathrm{~mL}$ of DMEM medium (Gibco, USA) containing 100units/mL of penicillin (Sigma, USA) and $100 \mathrm{mg} / \mathrm{mL}$ of streptomycin (Sigma, USA). Cells were grown in the same medium containing $20 \%$ fetal bovine serum (FBS, Sigma USA) at $37^{\circ} \mathrm{C}$ and $5 \% \mathrm{CO}_{2}$. After $90 \%$ of confluency, the cells were washed with phosphate buffer saline (1.15g Na2HPO4; $0.2 \mathrm{~g}$ $\mathrm{KH} 2 \mathrm{PO} 4 ; 8 \mathrm{~g} \mathrm{NaCl}$ and $0.2 \mathrm{~g} \mathrm{KCl}$ per liter, $\mathrm{pH}$ 7.2) twice and detached with the addition of $500 \mu \mathrm{L}$ of trypsin-EDTA $(0.25 \%$ trypsin in $0.53 \mathrm{mM}$ EDTA) at $37^{\circ} \mathrm{C}$ for $5 \mathrm{~min}$. The cells were transferred into tissue culture flask, propagated in DMEM containing 10\% FBS until $70 \%$ confluency and applied in 96 well (5000 cell/well) or 6 well plate $(15.000$ cell/ well) for further study. The cells were grown overnight in the same media, washed with $100 \mu \mathrm{L}$ of PBS and treated with various concentration of extract for $24 \mathrm{~h}$. We used anticancer tamoxifen to validate the assay. The treatment conditions were based on a report by Ningrum et al (2015) with some modifications.

\section{MTT assay}

Treated cells in 96 well plates were washed twice with $100 \mu \mathrm{L}$ of PBS. $100 \mu \mathrm{L}$ of DMEM with 10\% FBS containing MTT (Merck, Germany), with final concentration $0.5 \mathrm{mg} / \mathrm{mL}$, was added to each well. Cells were then incubated for $3 \mathrm{~h}$ and the medium was discarded. Formazan crystals that formed at the bottom of the well were dissolved in $100 \mu \mathrm{L}$ of SDS $10 \%$ in $0.01 \mathrm{M} \mathrm{HCl}$ (Septisetyani et al., 2014). The cells were incubated overnight and measured by spectrophotometery at $570 \mathrm{~nm}$. The percentage of the viable cell was compared to untreated control. $30 \mu \mathrm{M}$ of tamoxifen (Sigma, USA) was used as positive control. The experiments were done in triplicates in three dependent times.

Growth $(\%)=\frac{\text { OD }(\text { sample-blank })}{\text { OD }(\text { control-blank })} \times 100 \%$

\section{Viability staining}

Treated cells in 4 well plates were washed twice with $1 \mathrm{~mL}$ of PBS and stained with $500 \mu \mathrm{L}$ of $2 \mu \mathrm{M}$ calcein $\mathrm{AM}$ and $4 \mu \mathrm{M}$ ethidium bromide in PBS. The cells were incubated at room temperature for 45 minutes and observed under fluorescence microscope.

\section{RESULTS AND DISCUSSIONS Isolate Cultivation, Fermentation, and Extraction \\ It was reported that environmental} condition and interaction of endophytic microbe with the pathogens are the most influential factors of morphology variations 
(Araujo et al., 2002). In our previous research, we have molecularly identified K.Cl.Sb.B1 as Colletotrichum sp (Widowati et al., 2016). Several reports claimed that the species has antioxidant and cytotoxic activities (Tianpanich et al., 2011; Gangadevi and Muthumary, 2008; Chapla, 2014). The isolates were fermented in Potato Dextrose Broth medium. There were two fermentation results of endophytic fungi, biomass, and filtrate. The fungal filtrate was further extracted by ethyl acetate. We used ethyl acetate as a moderately polar solvent due to some advantage properties, such as volatile, relatively non-toxic, and non-hygroscopic (Linn, 1999). The yield quantification of dried fungal filtrate (Table I).

Table I. Yield quantification of the dried filtrate of endophytic fungi isolates from $2 \mathrm{~L}$ culture.

\begin{tabular}{lc}
\hline Isolate & Weight $\mathbf{( g )}$ \\
\hline K.Cl.Sb.R9 & 0.5877 \\
K.Cl.Sb.R11 & 1.0300 \\
K.Cl.Sb.A12 & 0.2669 \\
K.Cl.Sb.B1 & 0.5805 \\
\hline
\end{tabular}

\section{Inhibitory activity assay}

To validate the assay on MCF-7 cell line, we used commercial anticancer as a positive control. There are some cancer drugs that may be used as assay control, such as leucovorin, vinblastine, 5-fluorouracil, tamoxifen, interleukin-2, retinoic acid or folinic acid (Taylor et al., 1992; Lee et al., 1992; Lindner et al., 1997; Bernhard et al., 1992). Tamoxifen is cell-permeable anticancer and reversible inhibitor of protein kinase C. It also induces cell cancer apoptosis through the induction of p21 protein. Tamoxifen is a potent synthetic anti-estrogenic agent and cytostatic for estrogen-dependent cell line as well (Lippman and Bolan, 1975).

It was reported that tamoxifen inhibits proliferation of breast cancer cells by apoptosis induction. On MCF-7, Tamoxifen induces rapid death that mediated by extracellularly signal-regulated kinase signaling. The mechanism is ER-dependent and also assisted by ICI182780 insensitive nongenomic mechanisms (Zheng et al., 2007). Therefore, based on its activity, tamoxifen was chosen as a positive control in this research. MCF-7 is ER positive cell line that originated from human breast adenocarcinoma. We used MCF-7 as a model based on several studies which reported that some endophyte fungi had an inhibitory effect on its proliferation (Maemura et al., 1999; Katoch, 2014; Higginbotham, 2013). A study of endophyte fungi fusarium tricintum on MCF-7 cell line reported that the inhibition of cell growth highly associated with low production of inflammatory cytokine $\mathrm{TNF} \alpha$. TNF $\alpha$ has been known as a mediator of the inflammatory response that influence cancer growth (Vasundhara et al., 2016).

Inhibitory activity assay performed by using MT'T assay. We used SDS-0.01M HCl as solvent based on our previous optimization of solvent (Septisetyani et al., 2014). The most advantage of using SDS is the elimination of washing step which causes partially dissolved of formazan crystals. We applied a various concentration of samples ranging from 100 to $800 \mathrm{ppm}$. The $24 \mathrm{~h}$ treatment was chosen due to several publications of cytotoxic activity of endophytic fungi on MCF-7 cell line (Balakumaran et al., 2015; Vennila et al., 2012; Hulikere et al., 2016; Sadananda et al., 2016).

Table II. IC 50 of endophytic fungi on MCF-7 cell line growth inhibition

\begin{tabular}{lc}
\hline \multicolumn{1}{c}{ Isolate } & IC50 \\
\hline K.Cl.Sb.R9 & $579 \pm 38 \mathrm{ppm}$ \\
K.Cl.Sb.R11 & $542 \pm 21 \mathrm{ppm}$ \\
K.Cl.Sb.B1 & $446 \pm 15 \mathrm{ppm}$ \\
K.Cl.Sb.A11 & $520 \pm 28 \mathrm{ppm}$ \\
\hline
\end{tabular}

The result showed that the growth inhibition of MCF-7 cell line was dose dependent (Figure 1) with $\mathrm{IC}_{50}$ value of endophytic fungi was around $500 \mathrm{ppm}$ (Table II. In our previous research, 100ppm of fungal filtrate results in strong antioxidant activity (Bustanussalam et al., 2015). This denotes that the anti oxidant activity of endophytic fungi possibly more dominant comparing to inhibitory activity. Many studies reported various abilities of antiproliferative and antioxidant activities of endophytic fungi. 

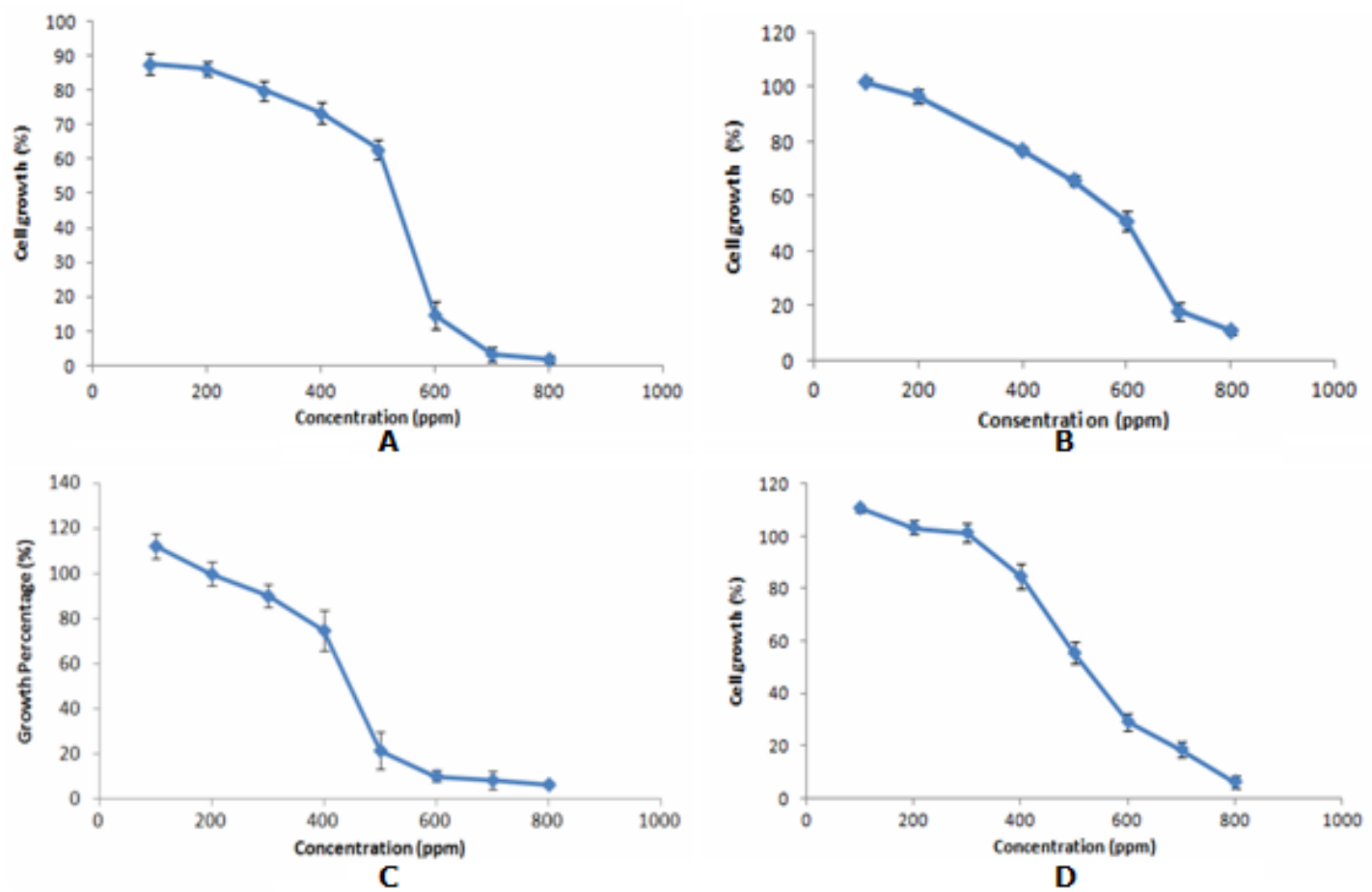

Figure 1. Inhibitory activity of endophytic fungi on MCF-7 growth by MTT assay. The Absorbance was read at 540nm. A=K.Cl.Sb.R9, B=K.Cl.Sb.R11, C=K.Cl.Sb.B1, D=K.Cl.Sb.A11

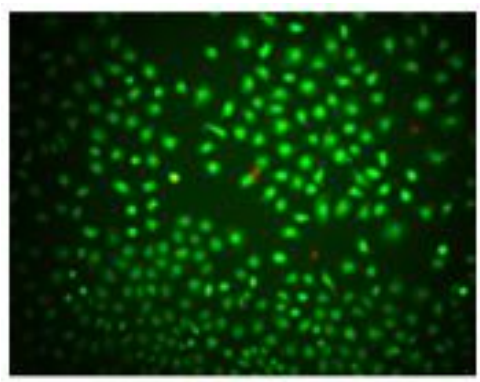

A

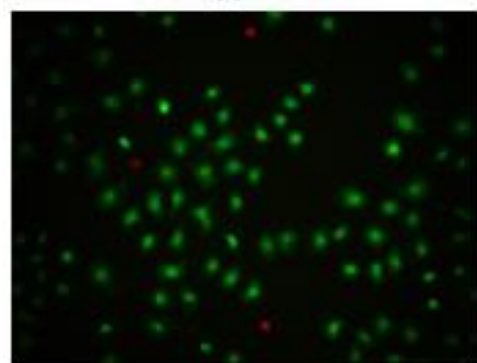

D

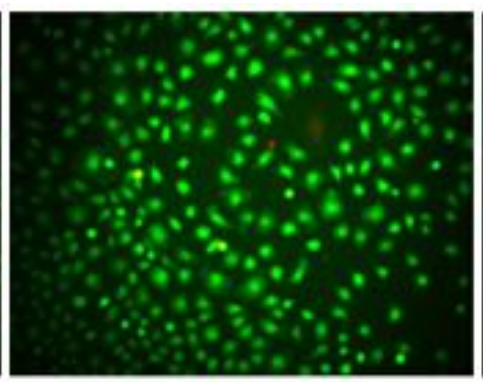

B

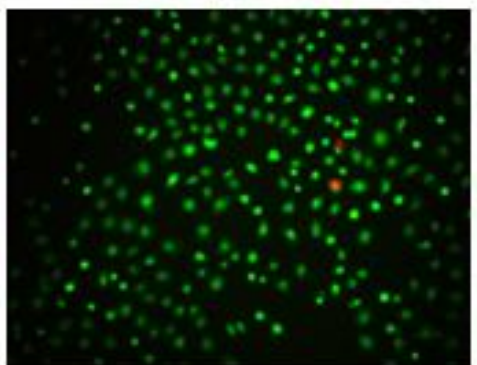

E

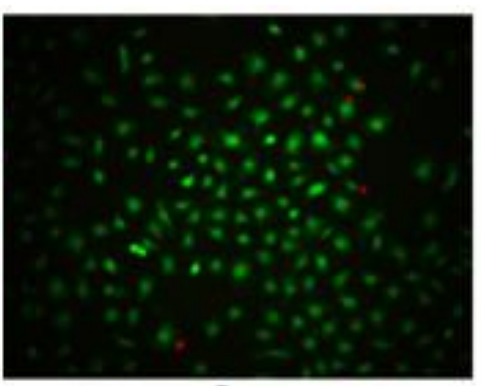

C

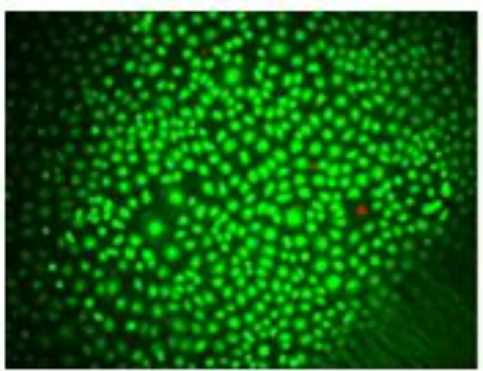

$\mathrm{F}$

Figure 2.Cell staining based assay of endophytic fungi on MCF-7 cell line. 10X magnification. The

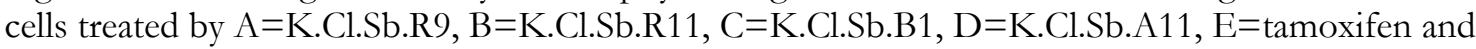
$\mathrm{F}=$ untreated 
Paraconiothyrium sp. P83F4 / 1 isolated from Rheedia brasiliensis known to have equal antioxidant and antiproliferation activities (Carvalho et al., 2012). However, endophytic fungi Fusarium tricinctum has more dominant antiproliferative than that of antioxidant (Vasundhara et al., 2016).

Inhibitory activity was furtherly confirmed by staining method using Calcein AM-ethidium bromide III fluorescent agents. The assay principle was based on measurement of two parameters of living cells, intracellular esterase activity as well as plasma membrane integrity. Calcein AM is nonfluorescent cellpermeant that can be enzimatically converted by esterase into intensely fluorescent calcein (Papadopoulos et al., 1994). The polyanionic dye calcein will retain within the living cells producing green fluorescence. Ethidium bromide III is non permeable fluorescent that excluded by intact plasma membrane of live cells. The dead cells will be stained as red colour. The advantage of using ethidium bromide III is $40 \%$ brighter than Ethidium bromide I (Papadopoulos et al., 1994).

The results revealed that all cells that treated with $500 \mathrm{ppm}$ of endophytic fungi filtrate have less living cell than that of the untreated (Figure 2). It was strongly indicated that the fungi had the ability to inhibit MCF-7 cell proliferation. Further characterization, such as gene expression and flowcytometry based analyses may need to confirm the results.

\section{CONCLUSIONS}

Endophytic

fungi K.Cl.Sb.R9,

K.Cl.Sb.A11, K.Cl.Sb. B1 and K.Cl.Sb.R11 isolated from Curcuma longa $L$ have the ability to inhibit the growth of human breast cancer MCF-7 cell line.

\section{ACKNOWLEDGMENTS}

This research would not be possibly completed without the support of Riset Kompetensi Inti 2016 from Research Center for Biotechnology, Indonesian Institute of Sciences.

\section{REFERENCES}

Alvin A., Miller KI., Neilan BA. 2014. Exploring the potential of endophytes from medicinal plants as sources of antimycobacterial compounds, Microbiological Research, 169(7-8): 483-495.

Arau'jo WL., Marcon J., Maccheroni Jr, W., van Elsas JD. Azevedo JL. 2002. Diversity of Endophytic Bacterial Populations and Their Interaction with Xylella fastidiosa in Citrus Plants. Applied and Environmental Microbiology. 68(10) : 4906-4914.

Ashraf A., Javaid A. 2005. Fungi associated with rhizome of turmeric (Curcuma longa L.) in Pakistan, Mycopath, 3(1/2): 6971.

Balakumaran MD., Ramachandran R., Kalaichelvan PT. 2015. Exploitation of Endophytic Fungus, Guignardia Mangiferae for extracellular Synthesis of Silver Nanoparticles and Their in Vitro Biological Activities, Microbial Research, 178, 9-17.

Bustanussalam Rahman F., Septiana E., Widowati T., Lekatompessy S., Sukiman, H., Simanjuntak P., 2015. Screening of Endophytic Fungi from Turmeric Plant of Sukabumi and Cibinong with Potency as Antioxidant Compound Producer, Pakistan J Biologycal sciences, 18(1): 42-45.

Bernhard H., Jäger-Arand E., Bernhard, G., Heike M., Klein O., Riemann JF., Meyer zum Büschenfelde KH., Dippold W., Knuth A.. 1995. Treatment of advanced pancreatic cancer with 5-fluorouracil, folinic acid and interferon alpha-2A: results of a phase II trial, British J. Cancer. 71(1): 102-105.

Carvalho P., Amaral P., Ruiz A., Alenca Sr., Pfenning L., Carvalho J., Rosalen P., Ikegaki M. 2012. Paraconiothyrium sp. P83F4/1: antioxidant and antiproliferative activities of endophytic fungus associated with Rheedia brasiliensis plant, Int J Biotechnology for Wellness Industries, 1, 172-176

Chapla VM., Zeraik, M. L., Leptokarydis, I. H., Silva, G. H., Bolzani VS., Young MC. M., Pfenning LH., Araujo AR. 2014. Antifungal Compounds Produced by Colletotrichum gloeosporioides, an Endophytic Fungus from Michelia champaca. Molecules. 19: 19243-19252. 
Dompeipen EJ., Simanjuntak P. 2015. Aktivitas antidiabetes dan antioksidan kapang endofit dari tanaman mahoni, Biopropal industri, 6(1): 7-17.

Gangadevi V., Muthumary J. 2008., Isolation of Colletotrichum gloeosporioides, a novel endophytic taxol-producing fungus from the leaves of a medicinal plant, Justicia gendarussa. Mycologia Balcanica, 5: 1-4.

Hulikere MM., Joshi CG., Nivvya T., Ananda D., Raju NG. 2016 Antiangiogenic and Antioxidant Activity of Endophytic Fungus Isolated from Seaweed (Sargassum wightii), Asian J Biochemistry, 11(4): 168-176.

Krup V., Prakash H., Harini A., 2013. Pharmacological Activities of Turmeric (Curcuma longa linn): A Review, Homeopathy \& Ayurvedic Medicine, 2(4) :1-5

Ikpeama, Ahamefula, Onwuka, GI. Nwankwo, C. 2014. Nutritional Composition of Tumeric (Curcuma longa) and its Antimicrobial Properties, International J Scien Eng Res, 5(10): 1085-1089.

Lee KH., Lee JS., Suh C., Lee YS., Min YI., et al 1992. The combination of 5-fluorouracil and recombinant interferon alpha- $2 \mathrm{~B}$ in advanced gastric cancer. A phase I study, Am J. Clin Onc. 15(2) : 141-145 P. 2011. Chemical composition and product quality control of turmeric (Curcuma longa L.), Pharmacentical Crops, 2011, 2: 28-54.

Lippmann ME., Bolan G. 1975. Oestrogenresponsive human breast cancer in longterm tissue culture. Nature, 256,593-595

Lin TB., Chung DL., Chang JR. 1999. Ethyl Acetate Production from WaterContaining Ethanol Catalyzed by Supported Pd Catalysts: Advantages and Disadvantages of Hydrophobic Supports, Industrial Engineering Chemistry Reports, 38(4): 1271-1276.

Lindner DJ., Borden EC., Kalvakolanu DV. 1997. Synergistic antitumor effects of a combination of interferons and retinoic acid on human tumor cells in vitro and in vivo, clinical cancer research. 3: 931-937.

Papadopoulos NG., Dedoussis GV., Spanakos G., Gritzapis AD., Baxevanis CN. et al., 1994. An improved fluorescence assay for the determination of lymphocytemediated cytotoxicity using flocitomety, J. Immunology Methods.

Maehara S., Ikeda M., Haraguchi H., Kitamura C., Nagoe T., et al, 2011, Microbial conversion of curcumin into colorless hydro derivatives by the endophytic fungus Diaporthe sp. associated with Curcuma longa, Chem Pharm Bull, 59(8) : 1042-1044.

Ningrum, R.A., Wisnuwardhani, P.H., Santoso, A., Herawati, N. (2015). Antiproliferative Activity of Recombinant Human Interferon alpha2b on MCF-7 cell line, Indonesian J. Pharm, 26(2): 86-93.

Ningrum RA., Wisnuwardhani PH., Santoso A., Herawati N. 2015. Antiproliferative Activity of Recombinant Human Interferon alpha2b on MCF-7 cell line, Indonesian JPharm, 26(2): 86-93.

Sadananda TS, Govindappa M., Ramachandra, YL., Chandrappa CP., Umashankar, T.2016. In Vitro Apoptotic Activity of Endophytic Fungal Lectin Isolated from Endophyte, Aspergillus flavus of Viscum album on Human Breast Adenocarcinoma Cell Line (MCF-7), Metabolomics, 6(1):1-7.

Septisetyani EP., Ningrum RA., Romadhani Y., Wisnuwardhani PH., Santoso A. (2014), Optimization of sodium dodecyl sulfate as a formazan solvent and comparison of MT'T assay with WST-1 assay in MCF-7 cells, Indonesian J Phar, 25 (4) : 245-254.

Singh, D., Rathod, V., Ninganagouda, S., Herimath J., Kulkarni P. 2013, Biosynthesis of the silver nanoparticle by endophytic fungi Penicillium sp. isolated from Curcuma longa (turmeric) and its antibacterial activity against pathogenic gram-negative bacteria, J. Pharm. Res, 7(5) : 448-453.

Suryanarayanan TS., Thirunavukkarasu N., Govindarajulu MB., Sasse F., Jansen R., Murali TS. (2009), Fungal endophytes and bioprospecting, Fungal biology review, 23: $9-19$.

Taylor CW., Modiano MR., Woodson ME., Marcus SG., Alberts DS. Hersh EM. 1992. A phase I trial of fluorouracil, leucovorin, and recombinant interferon 
alpha-2b in patients with advanced malignancy, Seminanr in Oncology. 19 (2 Suppl 3):185-190.

Tianpanich K., Prachya S., Wiyakrutta S., Mahidol C., Ruchirawat S., Kittakoop, P. 2011. Radical Scavenging and Antioxidant Activities of Isocoumarins and a Phthalide from the Endophytic Fungus Colletotrichum sp. J Nat Prod. 74, 79-81.

Vasundhara M., Baranwal M., Kumar A. 2016. Fusarium tricinctum, An Endophytic Fungus Exhibits Cell Growth Inhibition and Antioxidant Activity, Ind $J$ microbiology, 56(4):433-438.
Vennila R., Kamalraj S., Muthumary J. 2012, In vitro Studies on anticancer activity of fungal taxol against human breast cancer cell line MCF-7 cells, Asian Pacific J.Trop Biomed, S1159-S1161

Widowati T., Bustanussalam Sukiman H., Simanjuntak. P. 2016. Isolasi dan karakterisasi kapang endofit dari tanaman kunyit sebagai penghasil antioksidan, Biopropal industri, 7(1):9-16.

Zakiyah A., Radiastuti N., Sumarlin LO. 2013. Aktivitas antibakteri kapang endofit dari tanaman kina, Al kauniyah Jurnal Biologi, $8(2): 51-58$. 